\title{
Green microfinance promoting green enterprise development
}

\author{
Rouf, Kazi Abdur $\bowtie$ \\ Ontario Institute for Studies in Education, University of Toronto, Canada (rouf56@hotmail.com)
}

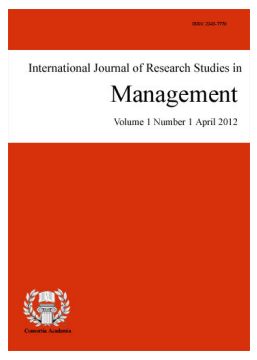

ISSN: 2243-7770 Online ISSN: 2243-7789

OPEN ACCESS

\section{Abstract}

Microcredit is a well known tool to address the issue of poverty that is a condition that affects the bottom fifty percent of people. Microcredit alleviates poverty by engaging communities in microloans and micro-businesses so that they may earn income. This new microeconomic determination program is expanding all over the world to develop economic growth in people's lives; however, if microfinance institutions are not controlled and they are provided to people who practice unsafe and non-eco-friendly businesses, the effect could be a minimalist microcredit approach that is unable to promote sustainable business development. To understand microcredit and renewable energy programs for green development, the researcher visited and studied Grameen Bank of Bangladesh; Grameen Shokti's Renewable Energy Project in winter 2008 and had an internship at the Alterna Savings' Community Micro-Loan Funds program in Toronto in the summer and fall of 2007 respectively. This paper envisions a comparison and contrasting of the Grameen Bank and Grameen Shokti credit systems (Bangladesh) with Alterna Savings credit programs (Canada) and its impact on Toronto's local living economics and environmental development. Results show that within the two sample cases, microcredits are positive to environmental sustainable development.

Keywords: Green microfinance; green enterprise; Grameen Bank; microfinance institutions (MFIs); solar home system; women empowerment; small and medium enterprises (SME)

Acronyms: Grameen Bank (GB), Grameen Shokti (GS), integrated pest management (IPM), Millennium Development Goals (MDGs), self-employment development initiative (SEDI), multi-national corporation (MNC), green microfinance institution (GMFI), world center for environmental development (WCED), non-government organizations (NGOs), energy savings company (ESCO), Royal Bank corporation (RBC), Trust Bank (TD), Alterna Savings Community Micro Loan Fund (ACMLF) 


\section{Green microfinance promoting green enterprise development}

\section{Introduction}

Microcredit is a well known tool to address the issue of poverty that is a condition that affects the bottom fifty percent of people. Microcredit alleviates poverty by engaging communities in microloans and micro-businesses so that they may earn income. This new microeconomic determination program is expanding all over the world to develop economic growth in people's lives; however, if microfinance institutions (MFIs) are not controlled and they are provided to people who practice unsafe and non-eco-friendly businesses, the effect could be a minimalist microcredit approach that is unable to promote sustainable business development. The result will be a microcredit program that not only neglects sustainable development, but destroys the earth and those who are more closely dependent on it rural communities. Therefore, recent, varied literature is urging for an integrated micro-financing program that has a central, socially responsible investment component. The components key feature would be the promotion of socio-cultural, environmental and business development while advancing social capital, human capital, and natural capital with economic growth. The matter of sustainable, people-centered environmental development is urgent.

To understand microcredit and renewable energy programs for green development, the researcher visited and studied Grameen Bank (GB) Bangladesh; Grameen Shokti's (GS) Renewable Energy Project in winter 2008 and had an internship at the Alterna Savings' Community Micro Loan Funds program in Toronto in the summer and fall of 2007 respectively. This was to gain valuable experience as it relates their green operational microcredit strategies, policies and programs. The researcher stayed in the villages and spoke with GB and GS borrowers. He also read various literatures on green microcredit. This paper envisions a comparison and contrasting of Grameen Bank and Grameen Shokti credit systems (Bangladesh) with Alterna Savings credit programs (Canada) and its impact on Toronto's local living economics and environmental development. The findings are positive to environmental sustainable development.

Green microcredit programs target micro-business owners in order to assist them in becoming economically self-sufficient through self-employment. They also help marginalized women entrepreneurs in their empowerment and promote community-based, local living development. GB Bangladesh has accomplished these socio-economic, environmental, sustainable green development features by creating its in-house, sector based institutional collaborative model. Contrarily in Canada, people are looking for public funds for poverty-related projects and for socially and environmental responsible investment projects. GB, GS Renewable Energy in Bangladesh and Alterna Savings in Canada are examples of green microcredit schemes that implement green business development programs. The purpose of the research is to examine the possibility of introducing market-based green business development in Canada that would model that of GB and its sister organizations.

\subsection{Thesis statement}

Within a microenterprise development model that has a positive environmental and social focus, microcredit programs can promote and achieve environmental, social and economic gains that are needed for the sustainable development of disadvantaged people.

Microcredit is a well known tool to address the issue of poverty that is a condition that affects the bottom fifty percent of people. Microcredit alleviates poverty by engaging communities in microloans and micro-businesses so that they may earn income. This new microeconomic determination program is expanding all over the world to develop economic growth in people's lives; however, if MFI's are not controlled and they are provided to people who practice unsafe and un-eco friendly businesses, the effect could be a minimalist microcredit approach that is unable to promote sustainable green business development. The result will be a 
microcredit program that not only neglects sustainable development, but destroys the earth and those who are more closely dependent on it in rural communities. Therefore, recent varied literature is urging for an integrated green social microfinancing program that has a central, socially green responsible investment component. This sustainable and people-centered environmental green social development program is urgent. Therefore, the research seeks to explore how microfinance can be structured to create sustainable development through green microenterprise while simultaneously achieving economic, social and environmental goals to address the issue of self-employment.

Green microcredit programs target micro business owners in order to assist them in becoming economically self-sufficient through self-employment. They also help marginalized women entrepreneurs in their empowerment and promote community-based, local living development. GB, Bangladesh has accomplished these socio-economic, environmental, sustainable green development features by creating its in-house, sector based institutional collaborative model. Grameen Bank, Grameen Shakti Renewable Energy in Bangladesh and Alterna Savings in Canada are examples of green microcredit schemes that implement green business development programs. The purpose of the research is to examine the possibility of promoting the small green businesses through green microfinancing to micro-entrepreneurs in Canada that would model that of GB and its sister organizations.

\subsection{Definitions of microfinance and green microfinance}

Microfinance is a program that involves serving the poorest communities in any one area or country, by providing them with soft loans to develop and maintain businesses. The program seeks to provide hands-on support to those who are interested in conducting businesses that better the communities in which they reside without providing harm as a result of their work. Green microfinance is the same sort of program, the difference is that soft loans are provided to individuals or groups of individuals who work directly to support sustainable green and social development, create green jobs and environmentally progressive solutions to practices that are destroying and polluting the earth.

This green microloan service follows the environmental mantra of: recycle, refine and reuse resources. Green businesses are not harmful to the environment, rather they accelerate green social development that is people-centered, fosters human health, promotes social justice, generates income, addresses the issue of poverty and reduces waste in the environment. It not only seeks profit, but it also looks at ecological balance within businesses, resources, the environment and society. Green microbusiness can increase marginalized people's income in order to survive, improve their quality of life as well preserve the environment.

\subsection{The importance of green microfinance}

Sustainable development and green business development, at the micro-level, need to focus on a goal that encompasses economic, social and environmental concerns. This view is shared by Allen and Thomas (2000); Anderson (2000); Chambers and Conway (1992); Colbert (2004); Hick (2004); McDonald and Oates (2006); Milani (2001); Prahalad and Hamel (2006); Slayter (2003); and Yunus (2002). They all mention that these are necessary elements for sustainable development; one that is able to contribute to the local economy, green development and sustainable livelihood at the local and national levels. There are obviously a number of reasons for the relevance of microfinance to the environment:

1. environmental concerns are very important to increasing the poor's standard of living and quality of life;

2. the most transformative green technologies and relationships are ideal for creating sustainable livelihoods as well as improving quality of life; and

3. microfinance is a decentralized form of investment, totally appropriate for decentralized green forms 
of production.

Of course, the concern is with the fact that conventional microcredit has not yet become green enough; however, few of them have built-in environmental conservation/development/education programs in their mainstream activities in addition to their focus on economic development practice.

Corporate waste; their toxic products and factory emissions, are spread in the air and water. Therefore, corporations hold the major brunt of responsibility for our environmental pollution. As a result, it is very important to reduce indoor air pollution. GB and GS (the energy arm of GB) are addressing these problems through the provision of microcredit to poor people and installing solar home systems; biogas produced in biogas plants and improved cooking stoves (ICS's) for renewable energy to use at the rural household level. Women cook with biogas instead of using wood, animal dung or other bio-fuels. This helps to save energy, use renewable energy and encourages environmental development.

In North America, energy consumption is a central issue. Every day, large amounts of waste are created by individual dwellings, restaurants, hospitals and factories. Packaging waste is also a large problem. Companies make products that end up as garbage, and tax payers become responsible for waste removal and management. Therefore, zero-waste, closed-loop protocols and shifting the responsibility for waste management to the manufacturing industry are vital to environmental protection. This degradable waste economy can be converted into a potential ecological economy through five stages of closed-loop production, cyclical alternative economical design, re-use of goods, repair of goods, reconditioning and rebuilding of goods, recycling materials and the production of life extension strategies. Here small and medium enterprises (SME) can play an important role in closed-loop ecological economics that can not only strengthen local living economics (LLE), but also protect the environment.

Integrated pest management (IPM) in agricultural systems reduces pesticide use by giving preference to non-chemical pest management strategies. Green MFIs can support farmers to initiate IPM services in the agricultural sector. Moreover, green social microcredit can play a vital role in attaining the United Nations Millennium Development Goals (MDG's) to eradicate poverty and promote environmental development.

\subsection{Problem statement}

While microfinance has emerged as a globally recognized development tool, today, there is barely any work being done that looks at the possibility of green microfinance practice through MFI's in Canada. Although several microfinancing domestic initiatives have been established in Canada, there is literature that recognizes mentions the lack of public policy as it relates to develop and support of a microfinance industry that would sustain and expand the green action micro lending program for low-income people in Canada (Self-Employment Development Initiative, 2007). However, the public has limited knowledge on the negative effects of chemicals on nature and human health, and corporations completely ignore the negative effects of chemicals on the human body and the environment. Therefore, environmental education on toxic chemicals, petroleum products and waste recycling management to the public through mass media, printed media, and school curricula are of a pressing matter in Canada.

Profit-generating, market-based multi-national corporation (MNC) activities create social inequity and unbalanced social-economic and environmental growth, harming the environment, and affecting climate change (increasing global warming, air pollution, water pollution and other environmental pollutions). Their businesses deplete natural resources through deforestation, river erosion, soil erosion and increased waste in the environment rather than supporting environmental justice. They are over extracting natural resources. They neither maintain, nor reforest nature.

Moreover, the micro green businesses compete with multinational corporations that are solely driven by profit; however, green microcredit and green microenterprises are balancing socio-economic and environmental 
need with development within society. For example, GB put "restrictions on giving loans to businesses" that are harmful to human health and the environment. Its sister organizations, like GS, largely work with soft loan credit. In addition to activities that supply solar panels, construct bio-gas plants, and improved cooking stoves. These help to activate rural energy, rural industries create rural employment and promote microenterprise.

\subsection{Rationality of the research}

Green micro financing and green micro business development, however, have been underserved. Less attention has been given by various public, private and non-governmental organizations (financial and non-financial) agencies through policies, strategies, and programs. Clearly many businesses are not serious about environmentalism because the values of environmental services are not appearing in business balance sheets. We cannot live without the environment. Moreover, unregulated financial services will undoubtedly result in greater negative environmental impacts and health hazards unless MFI practitioners ensure that this does not occur. Therefore, environmental issues are important for microenterprises that are nurtured by MFI's. In Canada, MFI's can support green micro businesses by providing business capital for green businesses, business training, mentoring services, marketing supports, and networking. They can finance environmentally-friendly businesses that produce solar panels, energy saving bulbs, solar water pumps and repair, recycle and reuse waste materials. Although microfinance models exist in some regions, they are neither national in scope nor available to all entrepreneurs in Canada. This researcher explores how both green social and economic components might be linked up within the context of sustainable development. It is expected that this process will contribute to the current knowledge base by identifying and seeking to fill the current gap in the literature.

\subsection{Objectives of the study:}

1. To study the operational practices of Canadian and Bangladeshi microcredit institutions in the area of gender empowerment, poverty alleviation and community organizing.

2. To compare microfinance programs, strategies, implementation and the relative success/failure of the programs in these two countries.

3. To explore the extent to which green microfinance is adopted in both countries, and to explore how lessons in microcredit in each of the two countries can inform improvements in the microfinance industry.

\section{Methodology}

The research methodology employed in this study is primarily qualitative and quantitative research method, literature reviews, seminars and field visit experience, interviews and case studies. To understand microcredit and renewable energy programs for green development, the researcher visited and studied GB Bangladesh, GS Renewable Energy Project in winter 2008 and had an internship at Alterna Savings' Community Micro Loan Funds program in Toronto in summer and fall 2007 respectively. This was to gain valuable experience as it relates their green operational microcredit strategies, policies and programs. The researcher stayed in the villages and spoke with GB and GS borrowers. He also read various literatures on green microcredit. This paper envisions a comparison and contrasting of GB and GS credit systems (Bangladesh) with Alterna Savings credit programs (Canada) and its impact on Toronto's local living economics and environmental development. The findings are positive to environmental sustainable development.

During the researcher's field visits in Bangladesh and in Toronto, he looked at the following questions to obtain answers from these organizations:

1. Which types of microcredit products, green products and projects are currently available to clients? Where are the projects located? 
2. What are the organizational structures, policies, procedures, strategies used to promote green microenterprise and operations in these organizations?

3. How many of the clients/beneficiaries have received gainful employment and/or social and environmental benefit through the projects? How are the projects contributing to sustainable development?

\section{Literature review}

The Sustainable Development Approach not only encompasses income-generation, but it is also a process that has people-centered development, green jobs creation, environmental development and poverty reduction (Allen \& Thomas, 2000; Habermas, 2002; Hopwood, Mellor, \& O'Brien, 2005; Joan \& Lal, 2006; Korten, 2006; Milani, 2001; Perkins, 2005; Sen, 1999). Cotula (2002) mentions that the sustainable development approach rests on core principles that are people-centered; multi-level; responsive and participatory, socially, environmentally and economically sustainable business practices, promotion mentorship and stewardship of the social economy. Therefore, it is necessary to examine current scholarly thoughts in the two areas which are currently treated separately.

GS is a renewable energy company established in 1996 with a view of promoting, developing and extending renewable energy technologies in the remote rural areas of Bangladesh. Its market-based renewable energy products are solar power, biogas, organic fertilizer, improved stoves and wind energy for the improvement of the quality life of rural communities. It provides necessary credit facilities for rural communities to access renewable energy technology. In addition, GS builds awareness and motivates rural communities towards adopting environmentally-friendly renewable energy (RE) technology. Its RE services are available all over Bangladesh through providing soft loans to renewable energy users.

Green micro business could be popular in Canada too, but it requires favorable legal frameworks, policies, strategies and a regulatory environment that has strong institutions with strong apex leadership to provide financial and non-financial services (Otero \& Rhyne, 1994). The Grameen Bank and Shore Bank USA have created millions of self-employment jobs in society. Green social microfinance for self-employment creation, green microenterprise development and for environmental innovations is of an urgent need in Canada, as its scope is broad and has massive demand.

Self-employment, in particular microenterprise development, has been rated by Statistics Canada as the fastest growing segment of the economy, which reduces social expenditures by governments and increases local economic transactions. The federal government has three programs to support self-employed Canadians: the Self-Employment Benefit (SEB), Program in Human Resource and Social Development Canada (HRSDC), and the Community Futures (CF) Program in Industry Canada. In the absence of a national self-employment framework, these programs are not as effective or accessible as they should be. Although some organizations like Alterna Savings, Vancity, and the Coady International Institute in Canada have started micro financing for micro business funding, they do not focus on green business financing for green micro business promotion.

In Toronto, Riverdale Business Development Corporation and Alterna Savings are centers of excellence within community-based development initiatives that help to create local jobs, develop local enterprises, and provide essential services to low-income people. As a starting point, these organizations could extend their loan services to recycling and waste management businesses. Alterna Savings Community Micro-loan Funds has just started its journey in 2000 as a carry forwarded from Calmeadow Foundation. It has now realized and extends its vision and mission to a socio-economic and environmental paradigm in collaboration with other stakeholders to minimize its costs.

\section{Green micro business, sustainable development and self-employment}


Green microfinance promoting green enterprise development

Sustainable development mostly concerns the environment and people's livelihood. Green business is more than clean-up and environmental protection (Milani, 2000). Green business is an alternative environmentally friendly oriented program for community-based ecological economics. Sustainable development promotes people-centered alternative development for social justice, environmental sustainability and is inclusive of everyone (Esbcobar, 1992; Hopwood et al., 2005; Korten, 2006; Rahman, 1997; Sen, 1999; World Commission on Environment and Development, 1987).

Grameen Bank provides loans to poor women for the improvement of their household economics as well as to generate social and human capital among them. In San Francisco, 230 investors have formed the New Resource Bank with a focus on financing "green" business and community and sustainable development (Self-Employment Development Initiative, 2007). Canada has not given this strategy sufficient consideration; even the non-profit sector has not considered this strategy significantly as a successful alternative.

Small businesses are less harmful to the environment. However, what cause small businesses to fail in Canada are a lack of to easily accessible credit/bank loans, high interest rates, and a lack of training in marketing, sales and business management. This poor access and lack of training is more acute for female entrepreneurs. In 1995, women owned 30.3\% of the businesses in Canada, and they employed 1.7 million people which are more than the country's 100 largest corporations (Longenceker, Moore, Petty, \& Palich, 1998). Nevertheless, women are having difficulty getting access to credit from banks and other support services. Contrarily GB has pioneered collateral-free small loan financing for women with enormous success that has created millions of self-employed in Bangladesh. Therefore, green social small financing programs are essential for the promotion of entrepreneurship in Canada.

\subsection{The practice of microfinance - The Bangladeshi and Canadian context}

GB follows the principle of Pancha Chakra. The Pancha Chakra model follows a loan disbursement cycle $(2+2+1)$ cycle- the neediest person receives a loan first followed by two others. The leader is the last one to receive the loan as discussed above. It has a weekly loan repayment system that helps clients to repay their loans in small installments. GB provides loans for activities on the farm, off the farm and non-farm related micro-enterprise in Bangladesh. It has participatory management with a bottom-up planning strategy where borrowers are owners of the bank.

The seventy percent energy crisis in Bangladesh hinders rural socio-economic and environmental development in Bangladesh. In this severe crisis situation, the GB Microcredit Program and GS Renewable Energy Program have been appropriately placed in Bangladesh to address the issue of poverty and to fill the energy gap in rural Bangladesh. GB provides loans based on more than 700 hundred items. The top twenty general loans are: milking cows, the fattening of cows, paddy husking, paddy cultivation, grocery shops, seasonal agricultural activities, rice trading, land leasing, irrigated agricultural cultivation, bullock, bamboo works, land management, stationary shops, vegetable cultivation, betel leaf cultivation, vegetable trading, clothing trading, fish farming, poultry farming, and winter crop cultivation. Here, all loans are environmentally-friendly and socially-responsible investments for poor people in rural Bangladesh.

The total number of borrowers of GB, up to December 2007, was 7.41 million. Ninety-seven percent of them were women. It works in 80,678 villages. GB's success is in high-volume lending, a strong loan repayment rate and high profit, which is well liked among development practitioners. GB operates nationwide through 2,185 branches. The repayment rate has been ninety-nine percent since 1979. The savings of current borrowers is $\$ 2.5$ billion. One hundred percent of loans are financed through borrowers' deposits (Grameen Bank, 2007). It runs on its own internal funds and investment income. This makes it economically sustainable. 
Rouf, K. A.

\section{Table 1}

Difference between Grameen Bank social credit and conventional credit

\begin{tabular}{ll}
\hline \multicolumn{1}{c}{ Grameen Bank credit } & \multicolumn{1}{c}{ Conventional Credit } \\
\hline Targets the bottom poor & Not focused on poor people \\
Greater focus on women & No focus on women \\
No physical collateral & Required physical collateral \\
Loan suitable for poor & Loan suitable for rich \\
Diversified loan portfolios & Fixed loan portfolios \\
Borrowers are owners of the bank & Borrowers are only clients \\
Social development opportunity at the grassroots' level & Opportunity open to rich people \\
Social development is an integral part of MCS & Social development is not first preference \\
Saving mobilization by members & No saving mobilization by clients \\
Intensive loan supervision & Causal supervision \\
Innovative leadership & Stereotypical of conventional leadership \\
Credit is considered to be a human right & Credit is at the mercy of the lender \\
Easy lending procedures & Lengthy and cumbersome method of lending \\
Builds entrepreneurial skills among the poor & \\
Loans for education, health care & No loan for health care, education \\
Egalitarian system & Isolated/rare integration/ elitist system \\
Humanitarian & Nonsensical \\
Mainly concentrated in rural areas & Urbanized \\
Customized policies and strategies in loan & operation, \\
developed in favor of borrowers & Top-down rigid, standardized policies not suitable for all \\
\hline
\end{tabular}

\begin{tabular}{|c|c|}
\hline Practice at implementation level & Success factor in GB \\
\hline Loan proposal through mutual decision among members & Exclusive focus on disadvantaged rural people \\
\hline Borrowers are free to select their activities & Manageable size of groups and centers to each worker \\
\hline Leakage free loan delivery system & Close subversion of loan utilization \\
\hline Weekly loan instilment with interest & Collective loan accountability \\
\hline Diversified loan disbursement with housing loan & Transparency in operation \\
\hline All transitions held in the Centre meeting & Decision making decentralized at the field level \\
\hline Regular monitoring on loan utilization & Staff dedication and mobility in the working area \\
\hline Proper documentation at all levels. & Disaster management integrated in the process \\
\hline Features of Implementation & Strong support of social development embodied 16 decisions \\
\hline Priority given to rural women & \\
\hline Credit discipline and close supervision in loan utilization & \\
\hline Bank goes to the borrowers houses & Extended banking facilities to the poor for self-employment \\
\hline Proper record keeping and transparency of transitions & Provide and support credit and activities \\
\hline Peer pressure and peer support in repayment & Develop programs, policies and implement them based on \\
\hline Collateral free loans for income generating activities & grass roots information and demand \\
\hline Compulsory regular group savings & Recruit local staff \\
\hline & Respect local culture and values \\
\hline \multicolumn{2}{|c|}{ GB Implementation Steps } \\
\hline GB works at the door step of the borrowers & Projection Meeting \\
\hline Borrowers form group of five men and women & Each group elects a Chair and a Secretary \\
\hline Each centre selects a Center Chief Peer pressure & Group savings and Individual savings \\
\hline
\end{tabular}

Figure 1. GB Successor Factors and Implementation Strategies 


\subsection{Grameen Shokti $(G S)$}

GS is a giant in renewable energy market-based action programs in Bangladesh. Only thirty percent of Bangladeshi people have access to grid electricity and most of them live in the cities. Many people cannot afford Solar Home Systems (SHS) individually. This is one of the barriers to scaling up the GS solar program and revitalizing the rural economy through the use solar PV technology. Sustainable energy is a combination of renewable energies like solar energy, energy from biomass and other saved energy. GS is an example of success in the renewable energy market in Bangladesh. Sustainable energy technologies (SETS) contribute to reducing poverty within a market-based integrated approach and providing energy for the poor in Bangladesh.

GS is also able to invest heavily in training for its field staff to develop their capacity to produce SHS accessories locally. The locally made accessories reduce costs of the renewable energy products. GS provides pre-and post-RE services to its clients through its Grameen Technology Centre (GTC) engineers and the trained local technicians from the GTC. Moreover, 25,000 school children from rural schools will receive exposure to RE technologies through 20 existing GTC's. More than 5,000 students have learned about renewable energy technologies through the existing GTC's.

GS has developed an integrated model which uses micro-utility innovatively to make renewable energy technologies affordable for rural people. Instead of being wholly dependable on subsidies, GS emphasizes its institutional strengths, as well as its commitment to borrowers, income-generation, entrepreneurship development, local technology transfer and capacity. Shopkeepers are now able to afford pollution-free, efficient lighting at minimal cost, while keeping their shops open after dusk with reduced health risks and less danger of fire. Kerosene lamps have now been replaced by SHS's.

GS statistics show that its total employees are 1800 who are mostly engineers. Within its 12-year span, its total unit offices are 365. The number of regional offices is 60 and the amount of divisional offices is 7 . The total amount of Grameen Technological Centers is 20. This covers 440 Upzilas (sub-districts) of 64 districts throughout Bangladesh. GS has expanded its activities to 32,000 villages out of 68,000 villages in Bangladesh. The GS report (Grameeen Shokti, 2008) indicates that GS has installed 130,000 SHS's and 5700 ICS's in Bangladesh. It has since installed 5000 SHS's and 700 ICS's and 250 biogas plants throughout Bangladesh. There is a large demand for solar energy in the villages, even in the urbanized areas. GS has developed a link with GB which has more than two million live stock farmers who receive loans from Grameen. These GB borrowers can construct biogas plants to meet their energy needs and can generate extra income from the production of biogas.

\subsection{Alterna Savings Toronto}

MFI's and different environmental, non-government organizations (NGOs) like energy savings company (ESCO) in Canada can play a great role in basic ecological and environmental education. The Business Alliance for Local Living Economics (BALLE) can advocate for related policies, facilitate partnerships between renewable solar panel suppliers, organic food suppliers, environmental NGO educators and MFI's. Alterna Savings, a community microloan program, offers small loans to small entrepreneurs for sustainable entrepreneurship development. Another objective of this organization is to create a supportive environment for self-employment among low-income people in the Greater Toronto area. It makes socially responsible investments in micro-entrepreneurs in Toronto and Ottawa.

As of December 2007, Alterna Savings total active loans were 122 and amounted to $\$ 567,574 ; 95$ loans were from the Toronto office which amounted to $\$ 397,000$. The loan repayment rate has been more than 91 percent. The Alterna Microloan Fund Program is an excellent program that promotes green economics in Canada. All of its borrowers invest loans into environmentally-friendly, small businesses. Alterna microloan borrowers receive loans for various training and business opportunities like computer training courses, webpage designing, 
computer repair, Child care, ESL learning centers, printing, grass cutting and trimming, cleaning services, restaurants, catering, shoe repair, tailoring, hair cutting and photography. In Bangladesh, microloan borrowers usually receive loans that serve agricultural and livestock rearing needs and tailoring needs.

\subsection{Mentor circle networking for Alterna borrowers}

In 2007, the Alterna Savings Micro Loan Fund Unit organized a networking café in its Bay and College Street office and facilitates workshop for its borrowers in the YMCA Central Hall every month. In the mentor circle networking Café, micro-entrepreneurs discuss action plans, marketing plans, goal setting and effective time management. This program facilitates peer support and networking among borrowers for their business growth. Alterna formed an environmentally-sustainable committee in 2008 that reviewed the credit union's footprint, and developed a long-term action plan. Its aim is to continue socially-responsible investing through its on-going membership education.

\subsection{Constraints faced by marginalized entrepreneurs in microenterprise development in Canada}

Canada has a strong cooperative and credit union movement and other community development initiatives, but they largely ignore the economic plight of marginalized Canadians. According to Self-Employment Development Initiative Canada (2007), the opportunities for green microfinance can be very lucrative to marginalized entrepreneurs in Canada, especially for women. Although Canada is a disposable society, the repair of cell phones, televisions, radios and computers is another way for entrepreneurs to participate in using green micro financing effectively. The opportunities for green micro financing with enough research can be wildly successful. Traditional financial institutions like Royal Bank (RBC) and Toronto Dominion bank (TD) Canada claim that they are unable to economically serve small business loans. Bank regulations are so rigid and tough that they are out of low-income people's range. These financial institutions do not share business risks with micro business owners. However, Alterna Savings' social auditing report 2006-2007 mentions that microenterprise development has proven to have a significant impact on the larger Canadian economy and individual households.

Green social micro financing can open the door for micro entrepreneurs graduating towards SME. Here people can start micro businesses with little money and develop their banking behaviors. The graduation process to SME is convenient for both financial institutions and clients, when investing more money into growing green businesses. In Canada, the main setback is the emphasis of MFI's on profit at the outset of the plan. However, Alterna Savings Community Micro Loan Fund in Canada is excellent in incorporating the fundamentals of socially responsible investments (SRI) in their mission and operation. Because they are the SRI green social businesses who avoid markets that are involved in alcohol, tobacco, gambling, weapons and various environmentally-hazardous businesses.

\subsection{Alterna savings and its social capital development activities}

The Networking Café-Mentors Circle program of Alterna Savings gives an opportunity to clients to network monthly. In the workshop, they discuss their business problems, review their performance, share experiences and get business stewardship training. The attendees of the mentor circle workshop have mentioned that it has helped them to focus on a task at hand and stay on track of their business. They can gradually ascend from small to medium to big business through receiving mentoring support services like access to sufficient business capital; access to public resources; marketing and networking supports from different institutions. Alterna Savings' community loan funds (ACMLF) provides loans to develop new immigrants' professional skills through vocational training to improve employability skills. Alterna supports sustainable and socially responsible goods and service enterprises. Alterna published its first corporate social responsibility accountability report in 2008, which contains social, environmental and financial performance records to its members, clients and communities. However, the Alterna Savings Micro Community Loan Fund and many other MFI's in Canada and in other 
countries do not articulate any clear policies in terms of renewable energy and basic environmental training of its clients. The Young Entrepreneur Financing Program administered by the Business Development Bank of Canada, whose aim is to give start-up entrepreneurs a foundation to build new businesses, does not yet have programs that include basic environmental services.

\subsection{Social Business Enterprise (SBE)}

According to Professor Muhammad Yunus (2008), it is time to move away from the narrow interpretation of business development through the paradigm of capitalist globalization and broaden the concept to include social financing, social economy and SBE. In the poverty situations, the GB credit program initiates and promotes alternative small business facilities in the villages in an effort to the acute environmental problems.

\subsection{Grameen as an example of social business}

Grameen Bank is a very good example of an integrative approach to the social economy and social business in Banngladesh. Grameen Danone is a hybrid SBE project in Bangladesh and went into operation in early 2007. Its shareholders are Group Danone Company, GS, GB, and Grameen Kallayan. Its dividends are not distributed to its shareholders Group Danone, GB, GS. GD produces Shokti Doi (Energy Yogurt) that is sold at a low price to rural children. These micro-lending institutions are examples that demonstrate that the concept of microfinance is rooted in local conditions. Green social microfinance promotes culture, heritage, and traditions of society, and promotes business and community networks.

\section{Conclusions}

Green microfinance and green microenterprise development are interrelated with each other. GS has developed an integrated model that facilitates socio-economic and environmental benefits in society and develops a financial self-sufficiency model for its renewable energy program, instead of subsidies. The link between the renewable energy soft financing model and biodiversity conservation helps fill the energy crisis gap in Bangladesh.

The entire process of a green micro lending program is a very intensive participatory process and requires a lot of capacity building and links with other implementing organizations. If these aspects are lacking, they create constraints on the success of the credit program. Although the financial costs for micro financing are high in Canada, because small amount of loans are given to many people, micro borrowers need more services than those who receive large commercial loans. However, the government, currently, does not put enough resources into this MFI program. These are the barriers in micro financing programs in Canada. However, green micro financing institutions (GMFI's) can support recycling projects through social enterprise funds. Loans can be used to reduce and recycle waste, generate local energy, and work with large institutions to implement better recycling, repairing and reusable projects. NGOs can provide training on recycling waste and renewable energy with targets to 'zero waste'. This is the essence of the ecological economy. This would help in the creation of many good green good jobs, the reduction of waste, and the preservation of our resources.

Metro Credit Unions, the Maytree Foundation and Alterna Savings Community Loan Fund program are aimed at developing financial capital for micro entrepreneurs; however, they do not streamline enough funds for micro lending to micro businesses in Canada; hence, Environment Canada can allocate resources and budgets to green microfinance institutions for implementing environmental social micro financing projects. Environment Bangladesh could provide supports that are consistent with local ecological demand. Environment Canada and environment Bangladesh can then help MFI and other environmental organizations in these two countries. With integrated support from public and private collaboration, GMFI's together can facilitate people-centered environmental sustainable development. 


\section{References:}

Allen, T., \& Thomas, A. (Eds.). (2000). Poverty and development into the 21st century. Oxford, UK: Oxford University Press.

Anderson, R. (2000). Climbing mount sustainability. Reflections, 1(4), 6-12. doi: 10.1162/152417300569890 $<$ http://dx.doi.org/10.1162/152417300569890>

Chambers, R., \& Conway, G. (1992). Sustainable rural livelihoods: Practical concepts for the 21st century (Vol. 296). Brighton.

Colbert, B. (2004). The complex resource-based view: Implications for theory and practice in strategic human resource management. The Academy of Management Review, 29(3), 341-358.

Cotula, L. (2002). Improving access to natural resources for the rural poor - The experience of FAO and of other key organizations from a sustainable livelihoods perspective. In H. E. Daly (Ed.), Ecological economics: The concept of sale and its relation to allocation, distribution, and uneconomic growth. Jasper, Alberta: CANSEE.

Esbcobar, A. (1992). Encountering development: The making and unmaking of the third world. Princeton, NJ: Princeton University Press.

Grameeen Shokti. (2008). Grameeen Shokti Report January 2008. Dhaka: Grammeen Shokti.

Grameen Bank. (2007). Grameen updates 2007. Dhaka: Grameen Bank.

Habermas, J. (2002). What does socialism mean today? In I. Kapoor (Ed.), The devil's in the theory: A critical assessment of Robert Chamber's work on participatory development: Carfax Publishing.

Hick, S. (2004). Social welfare in Canada. Toronto: Thompson Educational Publishing, Inc.

Hopwood, B., Mellor, M., \& O'Brien, G. (2005). Sustainable development: Mapping different approaches. Sustainable Development, 13, 38-52. doi: 10.1002/sd.244 <http://dx.doi.org/10.1002/sd.244>

Joan, H., \& Lal, A. (2006). How MFI's and their clients can have a positive impact on the environment. Paper presented at the Micro Credit Summit Campaign, Halifax.

Korten, D. (2006). The great turning from empire to earth community. Connecticut: Kumarian Press Inc.

Longenceker, J. G., Moore, C. W., Petty, W., \& Palich, L. E. (1998). Small business management. Toronto: Thomson Publishing.

McDonald, S., \& Oates, C. (2006). Sustainability: Consumer perceptions and marketing strategies. Business Strategy and the Environment, 15(3), 157-170. doi: 10.1002/bse.524 $<$ http://dx.doi.org/10.1002/bse.524>

Milani, B. (2000). Designing the green economy: The postindustrial alternative to corporate globalization. Lanham, MD: Rowman and Littlefield.

Milani, B. (2001). From opposition to alternatives: New productive forces and the post-materialist redefinition of wealth. Paper presented at the Environmental Studies Association of Canada (ESAC).

Otero, M., \& Rhyne, E. (1994). The new world of micro enterprise finance: Building healthy financial institutions for the poor. West Hartford, Connecticut: Kumarian Press, Inc.

Perkins, E. (2005). Feminist ecological economics and sustainability. Paper presented at the Canadian Society for Ecological Economics (CANSE). Toronto, York University.

Prahalad, K., \& Hamel, G. (2006). The core competence of the corporation. Harvard Business Review, 6(5), 79-92.

Rahman, A. I. (1997). Poverty, profitability of micro enterprises and the role of Credit. In G. Goeffrey Wood \& I. Sharif (Eds.), Who needs credit: Poverty and finance in Bangladesh. London: Zed Books.

Self-Employment Development Initiative. (2007). Self-employment development initiative. Retrieved June 7, 2008, from http://www.sedi.org

Sen, A. (1999). Development from freedom. New York: Anchor House.

Slayter, B. (2003). Southern exposure: International development and the global south in the twenty-first century. Bloomfield: Kumarian Press, Inc.

World Commission on Environment and Development. (1987). Our common future (The Brundtland Report). Oxford: Oxford University Press.

Yunus, M. (2008). Creating a world without poverty; Social Business and the future of capitalism. Dhaka: Subarna Publishers Limited.

Yunus, M. (2002). Grameen Bank 11: Designed to open new possibilities. Dhaka: Grameen Bank. 